3

4

5

6

7

8

9

10

11

12

13

14

15

16

17

18

19

20

21

22

23

24

25

26

27

28

29

30

31

32

33

(6)

\title{
Women Pay Their Way on Income Contingent Student Debt
}

\author{
Tracey West $\mathrm{a}^{\mathrm{*}}$
}

${ }^{a}$ Department of Accounting, Finance and Economics, Griffith University. Gold Coast, Australia.

* Corresponding author; Lecturer. Department of Accounting, Finance and Economics, Griffith University. Gold Coast QLD 4222 Australia. Tel: +61 7555 29769. Email: t.west@ griffith.edu.au. 


\section{Women Pay Their Way on Income Contingent Student Debt}

2

3

4

5

6

7

8

9

10

11

12

\section{Abstract}

Does the gender pay gap affect women's ability to repay their student debt? This study investigates the extent to which an income contingent scheme benefits women because of their individual earnings. Using the Australian HILDA Survey, gender differences in debt repayment behaviour over the past two decades is examined. The regression includes interaction terms for women that are risk-averse, of low socioeconomic status, low wealth, and low income. The industries where the majority of women are employed, education and health, are also examined. We find that over 2002 to 2014, women generally have less student debt than men, but those that are low income carry more debt. This is the first study to include an analysis of student debt by industry with a gender lens. Given the increasing amount of student debt Australians are carrying, it is important for policymakers to pay attention to its impacts to ensure fairness and equity.

Keywords: Student debt; HILDA; Women; Gender Pay Gap

Classification codes: D1 Household Behaviour and Family Economics; I22 Educational Finance, Financial Aid; I240 Education and Inequality 


\section{Introduction}

The benefits of higher education are well established for individuals in terms of relatively higher incomes and rates of employment (Barr 1998, 2004). The private rate of return has been quantified to be as high as 21.1 percent in Australia (Borland, Johnson and Williams, 2000). Such benefits are seen to justify shifting the higher education costs from taxpayers to students, particularly in the neoliberal environment (Chang and McLaren 2018, Nygreen 2018, Tesar 2019).

Australian students are advantaged by access to a student loan scheme that defers repayments until an income threshold is met. Australia introduced the first income-contingent loan (ICL) scheme to broaden higher education access and reduce the financial burden of higher education provision on government over 30 years ago. Other countries with wellestablished full or partial ICL schemes include England, New Zealand, the Netherlands, South Korea and Hungary (Britton, van der Erve and Higgins, 2018). The ICL scheme has progressive income thresholds for repayment. For example, the Australian ICL has nil repayment for those with gross incomes under $\$ 51,957$ and 2 percent of income is paid for those with incomes in the $\$ 51,957$ to $\$ 57,729$ income bracket in $2018-19$. Progressive increases in income brackets and repayment rates follow, with the top tier being 8 percent repayment on incomes over $\$ 107,214$.

Another major distinction of the Australian ICL scheme from student loans in other countries such as the United States (US), where many loans are privatised, is the treatment of interest. The Australian ICL scheme does not charge debtors interest, but balances are adjusted in June each year for inflation, established by the Consumer Price Index (CPI) that has averaged 2.4 percent over the last decade. In comparison, in 2018 interest rates for Federal loans in the US ranged between 5.0 percent to 7.6 percent, and private loans ranged from 3.9 to 14.3 percent (Kirkham 2019). The rate of interest for Federal Loans in the US is linked to the 10-year 
1 Treasury bond rate plus a fixed percentage. Changing the indexation from the CPI to the

2 Treasury bond rate, capped at 6 percent, was similarly proposed in Australia in 2014 through

3 legislation that did not pass Parliament (Dow 2014).

The purpose of the inflation adjustment is to maintain the real value of student debt on

5 the Government's balance sheet and reflect opportunity cost for the lender, functioning in a

6 similar manner as an interest charge. If the recipient pays off the ICL debt, they have paid the

7 principal borrowing amount plus an additional sum (the 'adjustment'), which is added to the

8 principal and thus compounds the debt. As compulsory repayments depend on income earned,

9 some recipients take longer than others to pay off the loan, thus incurring more 'adjustments' and compounding effects than others. If a recipient never pays off the loan, then they receive a larger subsidy from the government than others. Indeed, 21.8 percent of Australian ICL debts are unlikely to be repaid which equates to a significant amount of the total ICL debt forecasted to reach $\$ 11$ billion in 2025 (PBO 2016). Hence, Governments will continue to be motivated to review the current settings in the neoliberal environment. examined. Given increasing attention on the gender pay gap, it is timely to inspect whether a consequences. Given that women earn lower incomes than men and tend to have time out of 
1 Higher Education Contribution Scheme (HECS). See Parliament of Australia (2018) for an

2 explanation of these loan schemes and others.

3

4

5

6

7

8

9

The remainder of this paper has the following structure. The next section sets the context of the gender wage gap in Australia and the intention of the HELP scheme. Section 3 briefly reviews the literature on the impact of student debt on financial decision-making. The subsequent section explains the empirical methodology and the data employed in the analysis. Section 5 presents the results and Section 6 discusses the findings.

\section{Background of Gender and the Australian HELP Scheme}

The field of feminist economics despairs at assumptions underpinning 'rational' decision-making and policies made from a traditional masculinist model of reasoning, that favour the rights and needs of men (Gonzalez-Arnal and Kilkev 2009). Globally, the constraints of student debt schemes and gender shape decisions for university study and the labour market (Dwyer, Hodson and McCloud 2013). Dwyer et al. (2013) express the view that consideration of tertiary finance as a gendered issue is important for a number of reasons, including that (1) graduate incomes for female-dominated occupations may not pass the cost-benefit threshold for tertiary study; (2) the gender pay gap for women is particularly large for jobs that do not require a tertiary qualification and the gender pay gap reduces student debt repayment capacity; (3) women may have fewer options for jobs that do not require tertiary qualifications, and therefore feel pressured to attend university; and (4) women may want more support during study than men, including for academic preparation, family support, and peer networks, and therefore drop out or do not attend at all. Thus, returns on higher education are likely to be differentiated, and indeed for some, not guaranteed (Gonzalez-Arnal and Kilkev 2009).

Given these factors, one could argue that women are advantaged by the HELP scheme. The high-income thresholds and income contingency mean that women may not earn enough 
to pay off the debt over their working lives and thus their education has been heavily subsided by the Government. It is an intended outcome that the design supports equity of access and places the burden of repayment on those that can afford to pay (Barr, 1998).

However, a report by The Grattan Institute in 2016 put the spotlight on women. The author of the report entitled 'HELP for the Future: Fairer Repayment of Student Debt' stated that "the major cause of HELP's problems is that debtors who earn less than its initial threshold...do not repay" and that "women's repayment rates are critical to HELP's finances" (Norton 2016, 18). Additionally, Norton (2016) argues that half of HELP debtors should not feel financial strain from the extra repayment as many women live in a couple household with incomes that exceed $\$ 80,000$ per year. The crux of report was that if the initial repayment threshold was lowered more women would be captured in the compulsory repayment and thus in aggregate more of the HELP debt outstanding would be paid down.

Off the back of this report, the Parliament passed a reform in 2018 to reduce the initial repayment threshold from $\$ 51,957$ to $\$ 45,000$ (with a reduction in the initial threshold repayment rate from 2 percent to 1 percent). For those with incomes of $\$ 45,000$ per year, the HELP repayment would be \$9 a week. The legislation ((Higher Education Support Legislation Amendment (Student Loan Sustainability) Bill 2018) stated that the purpose of the change is to improve the sustainability of the HELP scheme by bringing more individuals into the repayment scope over time, while acknowledging the higher and sooner repayment of HELP for some students may reduce access to higher education. In particular, it is noted that there are disproportionate impacts on women and other low-income groups:

The Government currently carries a higher deferral subsidy from demographic groups that tend to have lower incomes. This includes women, individuals in parttime work, or individuals in low paid professions. As a result, some of these individuals, including women, may be making repayments for the first time as a 
result of the introduction of a lower minimum repayment threshold. Addressing this income inequality, however, is not the role of the higher education loans system.

Higher Education Support Legislation Amendment (Student Loan Sustainability) Bill 2018, pp 6-7.

In an era of rising awareness of a gender pay gap and its economic and societal impacts, policy reform that dismisses its impact on women seems ill-considered and ignores social justice factors (Chang and McLaren 2018, Nygreen 2018). While, as Norton (2016) argues, many women live in couple households with household incomes that can afford the $\$ 9$ per week, the remainder may comprise of lone people and lone parent households, trying to work and support dependents. Divorce rates of 2 per 1,000 people also indicate that some of the coupled women may separate, taking their HELP debt with them (AIFS 2019).

The gender pay gap in Australia ranges between 17.3 percent to 26.7 percent, depending on seniority of position and industry. An analysis by the Workplace Gender Equality Agency (WGEA) in 2018 of 4 million employees and 11,000 employers finds significant gender pay gaps remain once compositional differences between men and women are accounted for and comparing like-for-like remuneration (controlling for level of occupational seniority, industry and employment status). Thus, inequalities in pay between men and women are not explained by the different ways that men and women work, or the different roles that women and men play at equivalent occupational levels within an organisation. The report finds that more organisations than ever before are taking specific actions on pay equity, such as pay gap audits and analysis (WGEA 2018).

Given that organisations are reassessing policies through a gender lens, government should be motivated to do the same. There are consequences for government at the aggregate level. For example, women under financial strain because they are low income or because they 
make repayments over longer periods of time, have less financial capacity to save for unforeseen life events and retirement, thus putting pressure on the public purse. In addition, this money is withheld from spending, reducing economic activity.

\section{Review of the literature}

The literature on student debt is concentrated in the United States, where student debt was recently labelled a $\$ 1.5$ trillion crisis (Friedman 2018). High student debt levels are found to have a negative impact on some individuals' financial decisions and circumstances (Williams and Oumlil 2015) which of itself can be a barrier to participating in tertiary education (Burdman 2005; Linsenmeier, Rosen and Rouse, 2006). Higher instances of late bill payment, credit denials, increased applications for hardship, as well as other social and economic disadvantages are examples of the impacts of high student debt (Bricker and Thompson 2016; Despard et al. 2016). Further, having large student debts can make unforeseen events especially hard to navigate, like job loss, divorce, and illness (Dwyer et al. 2013). Student debt has been linked with financial stress, anxiety and depression. Financial stress also has a negative impact on academic performance (Archuleta, Dale and Spann, 2013). In aggregate, high student debt can have negative consequences on productivity and economic growth (Barros, Guironnet and Peypoch 2011, Ferretti, Jones and McIntosh 2016).

American and Canadian research supports the contention that the cost of study affects student diversity (Despard et al. 2016, Jackson and Reynolds 2013, Javine 2013, Woloschuck, Lemay and Wright 2010). In Australia and England, students from low socio-economic backgrounds, as well as women, older students, single parents, and students with family responsibilities, have all been found to be debt-averse and less likely to study if they will accumulate debt (Gonzalez-Arnal and Kilkev 2009, Marks 2009). An Australian survey of 7,000 high school students who were questioned regarding their intention to participate in 
1 higher education found that 39 percent of students from low socio-economic backgrounds

2 believed that costs might stop them from attending (James 2002). This finding compared to 23

3 percent of students from high socio-economic backgrounds. Wright (2005) also found that

4 student fees were the primary factor in study decisions of students from low socio-economic

5 backgrounds, leading to reduced participation in the Sydney region (Wright 2005). Students

6 expressed unease about the level of debt they incurred as a direct consequence of attending

7 university and commented on their lack of foresight in relation to the repayment of this money.

However, not all studies agreed. Andrews (1999) and Aungles, Buchanan, Kermel and MacLachlan (2002) did not find that the proportion of people from low socio-economic backgrounds had changed much over time. These findings support work from New Zealand (Tumen and Shulruf 2008) and the US (Waddell and Singell 2011) suggesting that increased student debt is not a discouraging factor and is, indeed, an effective vehicle for access among higher need students (Yezdani 2015). An experiment conducted recently by Bartholomae et al. (2019) that explicitly tested the impacts of gender in student debt borrowing decisions also found no significant gender differences.

Student debt has been linked to the delay of childbearing for women in the US and Australia (Bozick and Estacion 2014, Jackson 2002). However, other authors attributed the fact that women were having children at older ages to wider societal trends (Armstrong 2004). Nonetheless, this line of questioning triggered some evidence-based responses to investigating the issue of the impact of student debt on financial decision-making. In a survey of student nurses in New Zealand, for example, 69 percent of respondents indicated that having student debt was an impediment to further study, buying a home, and starting a family (O'Connor 2003). Student debt can also create problems in obtaining finance. A random sample of bank managers in New Zealand revealed that 51 percent had declined applications for finance and mortgages because of student debt (Pearse 2003). Other Australian research found no 
association of student debt with lower fertility expectations, but the magnitude of the student debt did affect parenthood decisions (Yu, Kippen and Chapman 2007).

Finally, there is limited literature relating to gender and repayment of student debt. A study by Saleh Leslie, Yu, and Seydel (2017) found that it takes women an average of 0.168 years' more salary than men to pay back student loans in the US. The authors state that "it clearly takes longer for females on average to repay their college loans than it does for males, and this serves as a major impediment to the financial success and equal progress of females in modern society" (p. 236). The American Association of University Women reported that four years after graduation, men paid off 44 percent of their student loan debt four years later, while women were only able to pay of 33 percent, due to the gender pay gap (Women in Academic Report 2016). Particularly disadvantaged were African American and Hispanic women, paying off 9 percent and 3 percent of student loans respectively over the same period. Examination of ten years of the Australian HILDA Survey (2001 to 2011) shows substantial repayment capacity differences between male and female debtors (Higgins and Sinning 2013). Average debt levels of male graduates drop relatively quickly over time, whereas female graduates' levels of debt remain constant, leading to projections that outstanding debt levels for female university graduates remain high while male balances are close to zero or very low. Data analysis of Australian Tax Office statistics raises further concern, as they reveal that the average time to make the first compulsory ICL payment (for both men and women) increased from 4.9 years in 2007 to 5.1 years in 2011, and the average time to repay the debt grew from 7.5 years in 2007 to 8.1 years in 2011 (Highfield and Warren 2015). Highfield and Warren (2015) however, did not provide an analysis of repayment by gender. 


\section{3. Data and Methodology}

The literature suggests that accumulating student debt can be a barrier to access higher education and can cause financial stress and other financial consequences post-study. In Australia, there has been some focus on the study decisions of low-socioeconomic status in this respect, with debt-aversion seen as one of the deterring factors. However, there is no study identified that investigates the repayment behaviour of people with these characteristics once holding student debt. It would be reasonable to assume that people that are low income, low wealth and low socio-economic status maintain higher levels of student debt because of the income contingent nature of the HELP scheme and reduced capacity to make voluntary repayments. It would also be reasonable to assume that risk-averse people behave similarly to debt-averse people, in that once they have accumulated the student debt, they pay it down at a faster rate than risk seeking people, if economically possible.

Further, the context of the gender pay gap and the HELP scheme highlights the need to understand the impacts of repayment capacity of women in more detail. Accordingly, the research questions focus on the repayment behaviour of women. As the gender pay gap can vary by industries, this study makes a novel contribution to the literature by investigating the HELP repayment behaviour of females in industries where females are most employed. An assumption is made that the gender pay gap in these industries means that women hold higher HELP balances than men.

Accordingly, the research questions are:

$\mathrm{H}_{1}$ : Females that are low income, low wealth, and low socio-economic status maintain higher levels of HELP

$\mathrm{H}_{2}$ : Females that are risk averse maintain lower levels of HELP 
$\mathrm{H}_{3}$ : Females in industries with highest female participation rates maintain higher levels of HELP

This study employs Waves 1 to 14 (corresponding to the years 2001 to 2014) of the Household, Income, and Labour Dynamics in Australia (HILDA) survey. HILDA tracks 7,682 Australian households comprising 19,914 individuals throughout their lives and is weighted to be representative of the Australian population. The HILDA survey is particularly useful for examination of student debt as the personal questionnaire asks respondents "Do you have any outstanding HECS debts or other student loans?" This question is followed by "How much do you still owe?"a These questions are asked in the Wealth Module, which is included every four years (Waves 2, 6, 10 and $14^{\mathrm{b}}$ ). Unfortunately, HILDA does not differentiate between student debt types, so the analysis relates to various ICL student debt schemes provided by the government in aggregate. ${ }^{c}$ Respondents may also report student loans from financial institutions that are not income contingent. Furthermore, student debt dollar amounts are reported by the respondent during the interview and may or may not have been cross-checked with official records as to the balance owing.

The HILDA sample information on HELP does also not perfectly correspond with the information provided by the Department of Education and Training (DET) (DET 2018). The HILDA student debtors comprise 8 percent of the sample in 2002, 8 percent in 2006,9 percent in 2010 and 12 percent in 2014. By comparison, DET (2018) reports that the proportion of the Australian population that had outstanding student debt (HELP debt) was 2 percent in 2002, 6 percent in 2006, 7 percent in 2010, and 9 percent in 2014. Thus, the HILDA sample is marginally overstated.

\footnotetext{
${ }^{a}$ HILDA still refer to the HELP system as HECS

${ }^{\mathrm{b}}$ Wave 18 not published at time of writing

${ }^{c}$ Possible student loans include HECS, HELP, HECS-HELP, VET Student Loans, VET FEE-HELP, FEEHELP, SA-HELP, OS-HELP, SSL, SFSS and TSL. See Parliament of Australia (2018) for an explanation of these loan schemes.
} 
1 Results must be interpreted within the limitations of the data. HILDA does offer

2 advantages over other datasets, such as that provided by the Australian Tax Office, in terms of generalisability and access to individual demographic and socio-economic factors.

The gender analysis of student debt is considered in four parts. First, descriptive statistics using the HILDA survey provides an overview of gender differences and trends over time. The descriptive statistics present participation rates and average balances of student debt for males and females, as well as by attitude to risk-taking, age, socio-economic status (SES), household type, year, education, wealth, personal income and industry classification.

Further descriptive statistics are provided by graphing cohort differences in HELP levels. Cohort differences are modelled by identifying when participants first responded positively to having student debt and grouping participants into cohorts based on the years 2002 or before, 2003 to 2006, 2007-2010 and 2011-2014. Students in the first cohort may have accumulated student debt any time before 2002, thus pushing down average student debts. Categories of average student debt owing were also generated to show the gender difference in the distribution across the sample.

Transition tables are used to illustrate the proportion of individuals moving between categories. Using a binary student debt variable, equal to one if HELP is greater than $\$ 0$, the category of interest in terms of understanding gender differences in HELP repayment is the proportion of individuals moving from 1 to 0 in the HELP binary variable. That is, who has held no student debt (0) in time $t$ but held student debt (1) in $t-1$.

Finally, a pooled regression model tests for the significance of gender and other demographic and socio-economic factors on HELP levels. Demographic and socio-economic factors include gender, age, education, personal income, household type, SES, wealth and attitudes to taking financial risk. The panel data regression model is as follows: 


$$
\begin{aligned}
\text {HELP }_{i j} & =\alpha_{j}+\beta_{1} \text { Year }+\beta_{2} \text { Gender }+\beta_{3} \text { Age }+\beta_{4} \text { Household type } \\
& +\beta_{5} \text { Education }+\beta_{6} \text { Fem } \times \text { SES }+\beta_{7} \text { SES }+\beta_{8} \text { Fem } \times \text { Low Wealth } \\
& +\beta_{9} \text { Wealth }+\beta_{10} \text { Fem } \times \text { Low Income }+\beta_{11} \text { Personal Income } \\
& +\beta_{12} \text { Fem } \times \text { No Risk }+\beta_{13} \text { Attitude to Taking Financial Risk } \\
& +\beta_{14} \text { Fem } \times \text { Education Industry }+\beta_{15} \text { Fem } \times \text { Health Industry } \\
& +\beta_{16} \text { Industry }+\mu_{i j}
\end{aligned}
$$

1

where:

HELP is the amount of outstanding student debt for person $i$ over time $j$. It is expressed in dollars. We confine the sample to people with HELP outstanding $(>\$ 0)$.

Year is a dummy variable for each wave of the Wealth Module.

Gender is a binary variable where female is (1) and males (0)

Age is a series of age category dummy variables, recoded from the HILDA continuous age variable. The categories include ages 16 to 24,25 to 34,35 to 44,45 to 54,55 to 64 and over 65 years.

Household Type is a series of household type dummy variables, recoded from twenty-eight HILDA household structure categories to four categories. These categories include couples with children, couple, lone parent and lone person households.

Education is a series of qualification dummy variables, where respondents nominate their highest qualification attained. The ten categories in HILDA have been recoded to three, where degree indicates a degree or higher educational qualification, a vocational qualification indicates further study after school that is not a university program, and Year11/12 is completion of school level education and unknown or undetermined education.

SES is a series of Socio-Economic Status categories, recoded from the ten Socio-Economic Indexes for Areas (SEIFA) classifications in HILDA to five. These categories include low 
1 SES (SEIFA 1-2), low-mid SES (SEIFA 3-4), mid SES (SEIFA 5-6), mid-high SES (SEIFA

2 7-8) and high SES (SEIFA 9-10)

3 Wealth is a series of household net wealth categories, recoded from a continuous variable in

4 HILDA. The categories include less than $\$ 499,000, \$ 500,000$ to $\$ 999,999, \$ 1,000,000$ to

$5 \$ 1,499,999$ and greater than $\$ 1,500,000$.

6 Personal Income is a series of personal income dummy variables for four categories. The

7 categories have been recoded from the continuous variable in HILDA. The categories include

8 personal income less than $\$ 19,999, \$ 20,000$ to $\$ 49,999, \$ 50,000$ to $\$ 99,999$ and $\$ 100,000$

9 and over. Low income earners are assumed to be those earning less than $\$ 19,999$ per annum,

10 approximately a quarter of Australian average earnings.

11 Attitude to risk-taking is derived from an attitudinal question in the Wealth Module, where respondents are asked to rate their level of willingness to take financial risks. We recode the response to positive risk taking, that include indicating 'substantial', 'above-average' and 'average' risks into a dummy variable 'risk-taking'. We recode those that indicated no appetite for risk-taking as 'no risk'. We dropped responses to the fifth option of 'I never have any cash' from being included in these variables for the purposes of our analysis.

Industry is a series of nineteen industry dummies from the Australian and New Zealand

Standard Industrial Classification (ANZSIC) 2006 division available in HILDA.

\section{Results}

Table 4.1 provides an overview HELP balances for women and male of selected demographic and socio-economic characteristics, averaged over the 2002 to 2014 sample period. The table shows that female HELP debtors were 60.9 percent (or 3,295 respondents) over the 2002 to 2014 sample, with an average student debt of $\$ 3,233.72$. Males comprises 39.1 percent of HELP debtors, with an average student debt of $\$ 3,189.68$. In 2002, female HELP debtors' average balances were \$1,713.67, and this increased to \$5,332.48 in 2014 . 
1 Males experience similar increases, averaging $\$ 1,653.92$ in 2002 and $\$ 5,292.49$ in 2014. In

2 general, female student debtors are slightly older than men, have higher levels of education, 534 years old.

6

6 lower levels of participation in the labour force, and lower rates of personal income than their male counterparts. Importantly, a very large portion of the student debtor population is under

2010 and then increased it in 2014. Reasons for this pattern for men is unknown, but labour market challenges related to the GFC may have increased return to study. The 2006 trajectory shows a hump shape for men, converging with the female trajectory in 2014. The 2010 trajectory shows more divergence between the female and male trajectories, with males having a much steeper gradient.

These data highlight worrying trends in HELP balances for both males and females. The cohort holding student debt since (at least) 2002 does not seem to be reducing its balances over time as much as would be expected. In fact, no downward trend is discernible. This finding is consistent with estimates of increasing average times to repay debt (Highfield and Warren 2015). The steeper gradients, or quicker escalation, of debts for more recent cohorts, combined with very long pay-down times observed, means student debts stay with the holder for quite a long time, which is not ideal for either the Government budget or the debt holder, especially if holding student debt has negative consequences for other financial decisions.

\section{<insert Figure 4.1 here>}

Further insight into repayment behaviours is provided by inspecting the transition tables on the binary HELP variable. Table 4.2, Panel (i) shows that for females, 94.73 percent of 
1 respondents have never held student debt, while 65.72 percent continue to hold student debt.

2 Over the sample period, 34.28 percent of respondents transitioned into having student debt, while 5.27 percent of females paid off student debt (transitioned out of holding student debt). A comparison of Panel A and B shows that the proportion of women that paid off student debt over the sample period was slightly more than that of their male counterparts $(5.27$ percent vs 3.68 percent). This trend is upheld in Panels (ii), (iii) and (iv) that show the change in states between each of the Wealth Modules. Interestingly, the HELP holders who stay in the same state $(1,1)$ have increased over time $(64.38 / 60.32$ percent in $2002-06,62.57 / 64.59$ in 2006-10, and 69.87/68.72 percent in 2010-14). This is a concerning trend for policymakers looking to reduce the HELP burden on the balance sheet.

<insert Table 4.2>

Regression results provided in Table 4.3 provide marginal effects, Jackknife standard errors and levels of significance for 10,508 observations. The adjusted r-square reports a goodness of fit of 11.06 percent, meaning there is significant variance not explained by the model. Generally, and reporting only on the statistical coefficients, HELP balances have increased over the years, they are larger in younger age groups, they are larger for university qualifications, and larger if you are in categories of high SES, high wealth, and mid-range personal income. Those that are willing to take financial risks also have slightly higher levels of HELP than the average. Those on high incomes, low SES, and a vocational qualification are likely to have less HELP balances than the average. Interestingly, all household types are significant and negative, meaning that people in these household types have HELP balances substantially under the average. For household structures where having children as dependents can strain household resources and result in gendered work/care decisions, such as couples with children and lone parents, the results are similar. The marginal effects coefficient are $5,922.36$ and $-5,417.67$, respectively. In comparison, Lone person households is $-8,580.27$ and 
1 couples are $-3,300.50$. In response to the Grattan Institute report, it seems there is some merit

2 to the assertion that those in coupled households have capacity to repay HELP debt.

Several variables of interest relating to females are not significant. The marginal effect

4 for gender is not significant, but the direction of the relationship between HELP balances and

5 being female is negative $(-1,127.11)$. Likewise, the interaction term for FemalexLow Wealth

6 is negative but not significant (-206.84) and FemalexNo Risk is very small and negative (-

7 1.39). While not significant, the direction of the change indicates that women in these categories maintain lower HELP balances than males. There could be several explanations for these results, but the most likely one is that women are studying in fields that don't accrue as much HELP as males, and/or have shorter programs of study. The descriptive statistics (transition tables in particular) show that there are just as many women as men with HELP over the sample period, so these results are unlikely to be due to women avoiding entering tertiary education. Alternatively, women in these categories make enough income to meet the repayment thresholds and/or make voluntary contributions in order to pay down HELP balance. More detailed information is needed to support these contentions, but it certainly appears that women maintain lower HELP balances than men, thus repaying their fair share. However, two of the interaction terms have positive coefficients. FemalexLow SES is not significant but is positive marginal effect $(1,026.14)$. In comparison to the low SES variable being significant at the 10 percent level and negative $(-1,552.33)$, this is worth noting. Females in this category may be finding it more difficult than their male counterparts to reduce their HELP balances. The other positive interaction term is FemalexLow Income (1,464.91), which is significant at the 10 percent level. Similarly, women in this category have higher HELP levels than men. The magnitudes of the two positive effects are not great compared to some of the other marginal effects reported (e.g. 2014 is 10,073.06), but it indicates women are finding it harder than their male counterparts to reduce the balance over time. 
Finally, the industries are examined, noting only two industries were significant.

2 Generally, people in the 'Health Care and Social Assistance' industry have $\$ 5,184.69$ more

HELP. This is likely to be associated with medicine, dentistry and other related professions where lengthy degrees and training are required. Those in the 'Accommodation and Food

5 Services' industry have $\$ 1,720.60$ less HELP, and degrees aren't necessary required. The

6 descriptive statistics showed that women are primarily employed in the 'Health Care and Social

7 Assistance' industry and the 'Education and Training' industry. Interaction terms were created for these two industries to see the HELP repayment behaviour of women in these industries.

The regression showed no significance for the two marginal effects. For women in Health though, they were likely to have $\$ 5,531.60$ less HELP than their male counterparts. This result is most likely attributed to the difference in the HELP debt associated with more femaledominated professions within the Health discipline, such as nursing.

\section{<insert Table 4.3>}

This analysis makes important contributions to the discourse on student debt. Overall, we find that the HELP repayment behaviour of women is marginally better than men and refutes the assertion by the Grattan Institute that there is a problem with women not paying their way. The results need to be interpreted within the limitations of the data and there are avenues for further research with higher frequency data. Nonetheless, the HILDA data does provide evidence that females in particular categories, such as low income and low SES, hold higher HELP balances than similar males. Notwithstanding the lack of significance, we provide partial support for $\mathrm{H}_{1}$ that females that are low income, low wealth, and low socio-economic status maintain higher levels of HELP. Regarding $\mathrm{H}_{2}$, the FemalexNo Risk interaction term was not significant and the magnitude very small, so we do not support the hypothesis that females that are risk averse maintain lower levels of HELP. They are on par with the average HELP balances. Finally, females in Health maintain lower HELP balances than their male 
1 counterparts, while females in Education have slightly higher balances. Thus, overall $\mathrm{H}_{3}$, that

2 females in industries with highest female participation rates maintain higher levels of HELP, 3 is not supported.

4

\section{5. Discussion}

6 This study makes several contributions to the literature. First, results add to the current 7 literature on student debt trajectories. By including an additional observation point (2014) the 8 study extends earlier work of Higgins and Sinning (2013) and provides new insights into cohort 9 differences, observing the increasing debt trends. Transition tables further report gender differences in HELP repayment behaviour over the whole sample period as well as in between Wealth Modules, and highlight concerning trends regarding the increasing proportion of HELP holders who do not pay off their balance.

We did not find gender to be a significant factor in the level of HELP balance, and for many of the female interaction terms, the direction of the relationship was negative. This means that there is no evidence that women are holding significantly higher balances of HELP than men which may happen if they are impacted by the gender wage gap or not paying down their fair share of HELP as asserted by the Grattan Institute. However, we did find that women in low SES and low-income categories were carrying more HELP than males in the same category. In the HILDA data averaged over the twelve-year period, the magnitude of these differences was relatively small $(1,026.14$ and $1,464.91$ respectively). Future research should revisit these statistics given the policy change to lower the initial income threshold for compulsory repayment in 2019.

This study makes a further contribution to the literature by examining the relationship between industry classifications and HELP balances. Further research could examine the 
1 returns on investment in education particular industries, or examine the field of study and the

2 industry working in. For example, the descriptive statistics show higher HELP balances for

3 industries such as Arts and Recreation Services, and Health Care and Social Assistance for

4 women.

5

While data is specific to Australia, the findings are important for higher education

6 policymakers internationally. In aggregate, high student debt can have negative consequences

7 on productivity and economic growth and widen the gender wealth gap (Barros et al. 2011;

8 Ferretti et al. 2016). Researchers and public policymakers are encouraged to monitor the

9 disquieting trends of increasing student debt balances that may produce different financial

10 outcomes for men and women. Future research on understanding whether prolonged holding of student debt changes the financial decision-making of women, including changing jobs, starting their own business, applying for loans or other activities is encouraged.

Geolocation Information: This article uses data that is representative of the Australian population.

Acknowledgements: This research did not receive any specific grant from funding agencies in the public, commercial, or not-for-profit sectors. The authors would like to acknowledge the reviewers for their highly constructive comments which make this paper more valuable.

Declarations of interest: none

Data Availability: Information about accessing the HILDA Survey dataset is available at https://melbourneinstitute.unimelb.edu.au/hilda

\section{References}


AIFS (Australian Institute of Family Studies) (2019) Divorce rates in Australia, Facts and Figures. Retrieved from https://aifs.gov.au/facts-and-figures/divorce-rates-australia.

Andrews L (1999) Does HECS deter? Factors affecting university participation by Low SES groups. Occasional paper series 99F, Department of Education, Training and Youth Affairs, Higher Education Division, Canberra. Retrieved from http://www.voced.edu.au/content/ngv\%3A15411

Archuleta K, Dale A and Spann SM (2013) College students and financial distress: Exploring debt, Financial satisfaction and financial anxiety. Journal of Financial Counselling and Planning, 24(2); 50-62.

Armstrong F (2004) The price of graduation: Is our system of funding for nursing education failing our students? Australian Nursing Journal, February, 22.

Aungles P, Buchanan I, Kermel T and MacLachlan M (2002) HECS and opportunities in higher education: Investigating the impact of the Higher Education Contributions Scheme (HECS) on the higher education system, Draft working paper. Canberra: Research, Analysis and Evaluation Group, Department of Education, Science and Training. Retrieved from http://pandora.nla.gov.au/pan/68064/20070219-

0000/www.dest.gov.au/sectors/higher_education/publications_resources/profiles/hecs_and_opp ortunities_in_higher_education_investigating.html

Barr N (1998) Higher education in Britain and Australia: What lessons? Australian Economic Review, 31(2); 179-188.

Barr N (2004) Higher education funding. Oxford Review of Economic Policy, 20(2); 264-282. doi: 10.1093/oxrep/grh015 Barros, C. P., Guironnet, J-P., \& Peypoch, N. (2011). Productivity growth and biased technical change in French higher education. Economic Modelling, 28(1-2), 641-646. doi: 10.1016/j.econmod.2010.06.005

Bartholomae S, Kiss E, Jurgenson JB, O’Neill B, Worthy SL and Kim J (2019) Framing the human capital investment decision: Examining gender bias in student loan borrowing. Journal of Family and Economic Issues, 40(1); 132-145.

Bozick R and Estacion A (2014) Do student loans delay marriage? Debt repayment and family formation in young adulthood. Demographic Research, 30(69); 1865-1981.

Bricker J and Thompson J (2016) Does education loan debt influence household financial distress? An assessment using the 2007-2009 survey of consumer finances panel. Contemporary Economic Policy, 34(4); 660-677. https://doi:org/10.1111/coep.12164

Britton J, van der Erve L and Higgins T (2018) Income contingent student loan design: Lessons from around the world, Economics of Education Review, online 21 June https://doi.org/10.1016/j.econedurev.2018.06.001.

Burdman P (2005) The student debt dilemma: Debt aversion as a barrier to college access. Research and Occasional Paper Series, Berkeley, CA: Centre for Studies in Higher Education, UC. Retrieved from https://cshe.berkeley.edu/publications/student-debt-dilemma-debt-aversionbarrier-college-access

Cameron AC and Trivedi PK (2009) Microeconometrics: Methods and Applications. Melbourne: Cambridge University Press

Carr J (2019) What is the average graduate salary in Australia? GradAustralia. Retrieved from https://gradaustralia.com.au/what-is-the-average-graduate-salary-in-Australia

Cassells R, Vidyattama Y, Miranti R and McNamara J (2009) The impact of a sustained gender wage gap on the Australian economy: Report to the Office for Women, Department of Families, Community Services, Housing and Indigenous Affairs. Retrieved from http://library.bsl.org.au/jspui/bitstream/1/1601/1/gender_wage_gap.pdf 
Chang, B and McLaren, P (2018) Emerging issues of teaching and social justice in Greater China: Neoliberalism and critical pedagogy in Hong Kong, Policy Futures in Education, 16(6); 781803.

Davis E and Lea SEG (1995) Student attitudes towards credit and debt. Journal of Economic Psychology, I; 663-679.

Department of Education and Training, Australian Government (2019) Annual Report 2016-17. Retrieved from https://docs.education.gov.au/system/files/doc/other/education_annual_report_2016-17_0.pdf

Despa S (2018) What is survival analysis? StatNews \#78. Retrieved from https://www.cscu.cornell.edu/news/statnews/stnews78.pdf

Despard MR, Perantie D, Taylor S, Grinstein-Weiss M, Friedline T and Raghavan R (2016) Student debt and hardship: Evidence from a large sample of low-and-moderate-income households. Children and Youth Services Review, 70; 8-18.

Dow, C (2014) Reform of the higher education demand driven system (revised), Budget Review 2014-15 Index. Retrieved from https://www.aph.gov.au/About_Parliament/Parliamentary_Departments/Parliamentary_Library/ pubs/rp/BudgetReview201415/HigherEdu

Dwyer RE, Hodson R and McCloud L (2013) Gender, debt and dropping out of college. Gender and Society, 27(1); 30-55.

Ferretti F, Jones S and McIntosh B (2016) Economic growth and the harmful effects of student loan debt on biomedical research, Economic Modelling, 49 (September); 308-313.

Friedman Z (2018, 13 June) Student Loan Debt Statistics in 2018: A \$1.5 Trillion Crisis, Forbes, Retrieved from https://www.forbes.com/sites/zackfriedman/2018/06/13/student-loan-debtstatistics-2018/\#c1286687310f

Gonzalez-Arnal S and Kilkey M (2009) Contextualising rationality: Mature student carers and higher education in England. Feminist Economics, 15(1); 85-111. https://doi.org/10.1080/13545700802528323

Ha H (2013) Credit card use and debt by female students: A case study in Melbourne, Australia. Youth Studies Australia, 32(4); 57-71. Retrieved from https://search.informit.com.au/fullText;dn=769059811260161;res=IELHSS

Hancock AM, Jorgensen BL and Swanson MS (2012) College students and credit card use: The role of parents, work experience, financial knowledge and credit card attitudes. Journal of Family and Economic Issues, 34(4); 369-381. Retrieved from https://link.springer.com/article/10.1007/s10834-012-9338-8

Higgins T and Sinning M (2013) Modelling income dynamics for public policy design: An application to income contingent student loans. Institute for the Study of Labour (IZA) Discussion Paper No. 7556. Retrieved from http://melbourneinstitute.unimelb.edu.au/assets/documents/hildabibliography/working-discussion-researchpapers/2013/Higgins_etal_Modeling_Income_Dynamics_for_Public_Policy_Design_dp7556.pdf

Highfield R and Warren N (2015) Does the Australian Higher Education Loan Program (HELP) undermine personal income integrity. eJournal of Tax Research, 13(1), 202-261. Retrieved from https://www.business.unsw.edu.au/research-site/publications-site/ejournaloftaxresearchsite/Documents/08_HighfieldWarren_HELP.pdf

Jackson N (2002) The Higher Education Contribution Scheme-A HECS on the Family? Joint Special Issue. Journal of Population Research and NZ Population Review, September; 105117. Retrieved from http://citeseerx.ist.psu.edu/viewdoc/download?doi=10.1.1.488.9587\&rep=rep1\&type=pdf 
Jackson B and Reynolds J (2013) The price of opportunity: Race, student loan debt, and college achievement. Sociological Inquiry, 83(3); 335-368. doi: https://doi.org/10.1111/soin.12012

James R (2002) Socioeconomic Background and Higher Education Participation: An Analysis of School Students' Aspirations and Expectations, Canberra: Australian Government Publishing Service. Retrieved from https://melbourne-cshe.unimelb.edu.au/research/past-researchprojects/equity/socioeconomic-background

Javine V (2013) Financial knowledge and student loan usage in college students, Financial Services Review, 22(4); 367-387.

Kirkham E (2019) What is the average student loan interest rate? The Balance. Retrieved from https://www.thebalance.com/average-student-loan-interest-rate-4684306

Knott M (2016) Collecting HECS from the dead on the table as the Turnbull government searches for savings. The Sydney Morning Herald. March 22. Retrieved from http://www.smh.com.au/federal-politics/political-news/collecting-hecs-from-the-dead-on-thetable-as-turnbull-government-searches-for-savings-20160317-gnl7kf.html>

Linsenmeier DM, Rosen HS and Rouse CE (2006) Financial aid packages and college enrolment decisions: An econometric case study. Review of Economics and Statistics, 88(1); 126-145. Retrieved from http://www.nber.org/papers/w9228

Marks GN (2009) The social effects of the Australian Higher Education Contribution Scheme (HECS), Higher Education, 57; 71-84. Retrieved from http://www.jstor.org/stable/40269107

Nelson B and Department of Education, Science and Training, Australia (2003) Our Universities: Backing Australia's Future. Canberra: Department of Education, Science and Training. Retrieved from http://www.voced.edu.au/content/ngv\%3A38781

Norton A and Cherastidtham I (2014) Mapping Australian Higher Education 2014-15, Grattan Institute. Retrieved from https://grattan.edu.au/wp-content/uploads/2014/10/816-mappinghigher-education-20142.pdf

Norton A (2016) HELP for the Future: Fairer Repayment of Student Debt, Grattan Institute. Retrieved from https://grattan.edu.au/wp-content/uploads/2016/03/968-HELP-for-thefuture1.pdf

Nygreen, K (2018) Neoliberal reform and family engagement in schools: An intersectional gender analysis, Policy Futures in Education, 17(2); 205-221.

O'Connor T (2003) Student debt is profoundly affecting nursing: An investigation into the impact of student loan debt has revealed its negative effects on nurses' personal, professional and family lives, Kai Tiaki: Nursing New Zealand, June. Retrieved from http://link.galegroup.com/apps/doc/A114701922/HRCA?u=griffith\&sid=HRCA\&xid=3d8eaa4 7

PBO (Parliamentary Budget Office) (2016) Higher Education Loan Programme, Report No. 02/2016. Canberra: Parliament of Australia.

Pearse H (2003) The Social and Economic Impact of Student Debt: Research Paper. Council of Postgraduate Associations Incorporated, March. Retrieved from http://www.capa.edu.au/wpcontent/uploads/2016/12/impact_of_student_debt.pdf

Saleh A, Leslie HS, Yu Q and Seydel J (2017) Gender equity, student loans and returns on investment in American higher education. International Journal of Sociology and Education, 6(2), 216243. Retrieved from file:///C:/Users/trace/Downloads/DialnetGenderEquityStudentLoansAndReturnsOnInvestmentInAm-6123256.pdf

StataCorp (2011) Stata: Release 12. Statistical Software. College Station,Texas: Stata Press Publication 
Stokes A and Wright S (2010) What are the alternatives to student loans in higher education funding? Contemporary Issues in Education Research, 3(1); 19-30. Retrieved from https://files.eric.ed.gov/fulltext/EJ1072557.pdf

Tesar, M (2019) Global politics and local impacts on educational policy, Policy Futures in Education, $17(3) ; 302-305$.

Tumen S and Shulruf B (2008) The effect of student loan schemes on students returning to study. Journal of Higher Education Policy and Management, 30(4); 401-414. Retrieved from https://www.tandfonline.com/doi/full/10.1080/13600800802383075?src=recsys

Waddell GR and Singell Jr LD (2011) Do no-loan policies change the matriculation patterns of lowincome students? Economics of Education Review, 30(2); 203-214. Retrieved from https://pdfs.semanticscholar.org/16fd/2f0ab8237f931fd7ce8931dfd4a64309d78c.pdf

Williams A and Oumlil B (2015) College student financial capability. International Journal of Bank Marketing, 33(2); 637-653. Retrieved from https://www.emeraldinsight.com/doi/full/10.1108/IJBM-06-2014-0081

Wright SJ (2005) The Impact of Changes in HECS on Students from Low Socio-Economic Backgrounds, Sydney: Greenacre Educational Publications.

Woloschuk W, Lemay J and Wright B (2010) What is the financial state of medical students from rural backgrounds during tuition fee deregulation? Canadian Journal of Rural Medicine, 15(4); 156-160. Retrieved from https://www.ncbi.nlm.nih.gov/pubmed/20875315

Women in Academic Report (2016) Gender Pay Gap for Recent College Graduates Impacts Ability to Pay Off Student Loan Debt. Bartonsville: United States. Retrieved from https://www.aauw.org/research/deeper-in-debt/

Workplace Gender Equality Agency (WGEA) (2018) Gender equity insights 2018: Inside Australia's gender pay gap. Retrieved from https://bcec.edu.au/assets/BCEC-WGEA-Gender-EquityInsights-2018-Report_WEB.pdf

Worthy SL, Jonkman J and Blinn-Pike L (2010) Sensation-seeking, risk-taking, and problematic financial Behaviours of college students, Journal of Family and Economic Issues, 31(2); 161170. Retrieved from https://link.springer.com/article/10.1007\%2Fs10834-010-9183-6

Yezdni O (2015) The nature of choice and value for services and amenities in Australian universities, Journal of Higher Education Policy and Management, 37(3); 282-294. Retrieved from https://www.tandfonline.com/doi/abs/10.1080/1360080X.2015.1034428

Yu P, Kippen R and Chapman B (2007) Births, debts and mirages: The impact of the Higher Education Contribution Scheme (HECS) and other factors on Australian fertility expectations, Journal of Population Research, 24(1), 73-90. Retrieved from https://link.springer.com/article/10.1007\%2FBF03031879 


\section{Appendix}

Table 4.1. Descriptive Statistics, Student Debt Holders

\begin{tabular}{|c|c|c|c|c|c|c|}
\hline \multirow[b]{3}{*}{ Parameter } & \multicolumn{6}{|c|}{ Student Debt, 2002-2014 } \\
\hline & \multicolumn{2}{|c|}{ Female } & \multirow{2}{*}{\multicolumn{2}{|c|}{$\begin{array}{r}\text { Proportion } \\
\text { of Total } \\
\text { Sample } \\
(\mathbf{N}=\mathbf{2 1 1 4}) \\
\end{array}$}} & \multicolumn{2}{|c|}{ Male } \\
\hline & $\begin{array}{r}\text { Proportion } \\
\text { of Total } \\
\text { Sample } \\
(\mathbf{N}=3295) \\
\end{array}$ & $\begin{array}{r}\text { Mean } \\
\text { Student } \\
\text { Debt } \\
\end{array}$ & & & $\begin{array}{r}\text { Mean } \\
\text { Student } \\
\text { Debt } \\
\end{array}$ & $\begin{array}{l}\text { Standard } \\
\text { Deviation } \\
\end{array}$ \\
\hline \multicolumn{7}{|l|}{ Year } \\
\hline 2002 & 0.186 & $1,713.67$ & $6,312.87$ & 0.199 & $1,653.92$ & $6,150.49$ \\
\hline 2006 & 0.191 & $2,013.07$ & $6,989.64$ & 0.179 & $2,008.35$ & $7,081.74$ \\
\hline 2010 & 0.230 & $3,150.42$ & $10,013.71$ & 0.235 & $3,071.06$ & $9,701.86$ \\
\hline 2014 & 0.392 & $5,332.48$ & $14,648.06$ & 0.387 & $5,292.49$ & $15,308.56$ \\
\hline Gender & 0.609 & $3,233.72$ & $10,586.88$ & 0.391 & $3,189.68$ & $10,800.46$ \\
\hline \multicolumn{7}{|l|}{ Age Category } \\
\hline $16-24$ years & 0.396 & $7,356.72$ & $15,341.76$ & 0.457 & $6,709.65$ & $5,663.27$ \\
\hline 25-34 years & 0.371 & $5,440.17$ & $13,219.40$ & 0.359 & $5,631.95$ & $13,848.34$ \\
\hline $35-44$ years & 0.149 & $1,700.90$ & $6,517.45$ & 0.118 & $1,643.92$ & $6,648.27$ \\
\hline $45-54$ years & 0.064 & $3,048.91$ & $11,142.00$ & 0.044 & $2,461.29$ & $10,229.24$ \\
\hline $55-64$ years & 0.017 & $1,754.63$ & $7,637.60$ & 0.018 & $2,110.82$ & $8,229.97$ \\
\hline Over 65 years & 0.003 & 239.18 & $2,526.61$ & 0.004 & 222.78 & $2,171.75$ \\
\hline \multicolumn{7}{|l|}{ Household Type } \\
\hline Couple with children & 0.401 & $3,876.80$ & $11,436.52$ & 0.384 & $3,708.97$ & $1,650.53$ \\
\hline Couple & 0.259 & $2,705.91$ & $10,312.35$ & 0.241 & $2,616.21$ & $10,074.19$ \\
\hline Lone parent & 0.121 & $3,256.57$ & $9,832.64$ & 0.079 & $3,711.72$ & $10,868.50$ \\
\hline Lone person & 0.159 & $1,700.79$ & $6,798.95$ & 0.206 & $1,556.58$ & $6,091.57$ \\
\hline \multicolumn{7}{|l|}{ Education } \\
\hline Bachelor's degree and above & 0.510 & $6,697.87$ & $15,510.91$ & 0.438 & $6,605.79$ & $16,878.06$ \\
\hline Vocational qualification & 0.171 & $2,248.67$ & $8,021.73$ & 0.143 & $1,905.14$ & $7,426.13$ \\
\hline Year $11 / 12$ & 0.319 & $2,200.15$ & $8,483.97$ & 0.420 & $2,668.23$ & $9,103.33$ \\
\hline \multicolumn{7}{|l|}{ Socio-Economic Status } \\
\hline Low SES & 0.137 & $1,814.57$ & $6,838.98$ & 0.130 & $1,744.60$ & $6,726.87$ \\
\hline Low-Mid SES & 0.173 & $2,555.75$ & $8,325.01$ & 0.173 & $2,519.67$ & $8,559.41$ \\
\hline Mid SES & 0.198 & $2,812.52$ & $10,470.54$ & 0.173 & $2,835.53$ & $11,772.44$ \\
\hline
\end{tabular}




\begin{tabular}{|c|c|c|c|c|c|c|}
\hline Mid-High SES & 0.237 & $4,023.11$ & $11,684.00$ & 0.246 & $4,050.57$ & $11,762.59$ \\
\hline High SES & 0.253 & $4,993.36$ & $13,909.36$ & 0.279 & $4,749.39$ & $13,410.90$ \\
\hline \multicolumn{7}{|l|}{ Wealth } \\
\hline$<\$ 499,000$ & 0.732 & $3,242.22$ & $10,355.59$ & 0.727 & $3,305.75$ & $10,493.71$ \\
\hline$\$ 500,000-\$ 999,999$ & 0.154 & $2,942.87$ & $9,409.66$ & 0.132 & $2,686.78$ & $8,938.35$ \\
\hline$\$ 1,000,000-\$ 1,499,999$ & 0.05 & $3,266.76$ & $10,134.96$ & 0.064 & $3,138.13$ & $9,901.08$ \\
\hline$>\$ 1,500,000$ & 0.06 & $3,755.71$ & $14,045.28$ & 0.078 & $3,559.98$ & $15,405.39$ \\
\hline \multicolumn{7}{|l|}{ Personal Income } \\
\hline Less than $\$ 19,999$ & 0.369 & $2,783.94$ & $9,725.02$ & 0.344 & $2,918.56$ & $9,672.01$ \\
\hline$\$ 20,000$ to $\$ 49,999$ & 0.400 & $3,253.39$ & $10,373.23$ & 0.365 & $3,243.22$ & $11,509.74$ \\
\hline$\$ 50,000$ to $\$ 99,999$ & 0.214 & $4,383.82$ & $12,964.19$ & 0.243 & $3,365.32$ & $11,053.70$ \\
\hline$\$ 100,000$ and over & 0.017 & $2,656.18$ & $8,777.14$ & 0.049 & $3,306.46$ & $10,958.54$ \\
\hline \multicolumn{7}{|l|}{ Attitude to Risk-Taking } \\
\hline No Risk & 0.366 & $2,945.66$ & $9,771.48$ & 0.240 & $2,638.77$ & $9,469.63$ \\
\hline Risk-Taking & 0.360 & $3,807.76$ & $11,910.35$ & 0.487 & $3,751.45$ & $12,234.34$ \\
\hline \multicolumn{7}{|l|}{ Industry } \\
\hline $\begin{array}{l}\text { Agriculture, Forestry and } \\
\text { Fishing }\end{array}$ & 0.005 & $1,184.47$ & $5,405.14$ & 0.015 & $1,570.57$ & $6,907.44$ \\
\hline Mining & 0.003 & $2,193.33$ & $6,650.35$ & 0.010 & $2,744.48$ & $9,431.26$ \\
\hline Manufacturing & 0.023 & $3,009.83$ & $9,498.72$ & 0.044 & $2,297.24$ & $8,310.12$ \\
\hline $\begin{array}{l}\text { Electricity, Gas, Water and } \\
\text { Waste Services }\end{array}$ & 0.002 & $1,891.59$ & $5,252.31$ & 0.007 & $3,434.84$ & $10,436.27$ \\
\hline Construction & 0.007 & $2,332.10$ & $7,178.67$ & 0.042 & $2,369.55$ & $8,716.59$ \\
\hline Wholesale Trade & 0.010 & $2,743.45$ & $9,048.44$ & 0.018 & $2,506.40$ & $8,194.09$ \\
\hline $\begin{array}{l}\text { Retail Trade } \\
\text { Accommodation and Food }\end{array}$ & 0.108 & $4,537.39$ & $11,828.48$ & 0.115 & $5,070.06$ & $12,355.19$ \\
\hline Services & 0.071 & $4,376.48$ & $11,576.55$ & 0.071 & $4,642.15$ & $15,937.06$ \\
\hline $\begin{array}{l}\text { Transport, Postal and } \\
\text { Warehousing } \\
\text { Information, Media and }\end{array}$ & 0.006 & $1,931.24$ & $9,800.80$ & 0.026 & $2,472.19$ & $10,107.04$ \\
\hline Telecommunications & 0.022 & $5,307.48$ & $23,136.23$ & 0.021 & $4,178.38$ & $11,402.17$ \\
\hline $\begin{array}{l}\text { Financial and Insurance } \\
\text { Services }\end{array}$ & 0.025 & $3,589.45$ & $10,811.49$ & 0.035 & $2,425.32$ & $14,705.33$ \\
\hline $\begin{array}{l}\text { Rental, Hiring and Real } \\
\text { Estate Services }\end{array}$ & 0.008 & 3.331 .15 & 11.805 .29 & 0.010 & 3.838 .85 & 10.733 .66 \\
\hline
\end{tabular}




\begin{tabular}{|c|c|c|c|c|c|c|}
\hline $\begin{array}{l}\text { Professional, Scientific and } \\
\text { Technical Services }\end{array}$ & 0.077 & $5,826.61$ & $14,204.30$ & 0.110 & $6,387.61$ & $16,718.93$ \\
\hline $\begin{array}{l}\text { Administrative and Support } \\
\text { Services }\end{array}$ & 0.018 & $3,001.02$ & $9,804.00$ & 0.019 & $3,544.25$ & $10,528.02$ \\
\hline $\begin{array}{l}\text { Public Administration and } \\
\text { Safety } \\
\text { Education and Training }\end{array}$ & $\begin{array}{l}0.036 \\
0.148\end{array}$ & $\begin{array}{l}3,591.28 \\
5,514.31\end{array}$ & $\begin{array}{l}10,164.45 \\
12,743.72\end{array}$ & $\begin{array}{l}0.050 \\
0.087\end{array}$ & $\begin{array}{l}3,780.47 \\
5,708.27\end{array}$ & $\begin{array}{l}11,013.75 \\
12,303.88\end{array}$ \\
\hline $\begin{array}{l}\text { Health Care and Social } \\
\text { Assistance }\end{array}$ & 0.175 & $4,449.65$ & $12,449.52$ & 0.065 & $6,682.30$ & $18,383.99$ \\
\hline Arts and Recreation Services & 0.022 & $5,837.91$ & $13,876.75$ & 0.027 & $5,676.53$ & $16,438.66$ \\
\hline Other Services & 0.017 & $3,265.87$ & $10,287.56$ & 0.024 & $2,995.68$ & $9,184.35$ \\
\hline
\end{tabular}

\begin{tabular}{|c|c|c|c|c|c|c|}
\hline \multirow[b]{3}{*}{ Parameter } & \multicolumn{6}{|c|}{ Student Debt, 2002-2014 } \\
\hline & \multicolumn{2}{|c|}{ Female } & \multirow{2}{*}{\multicolumn{2}{|c|}{$\begin{array}{r}\text { Proportion } \\
\text { of Total } \\
\text { Sample } \\
(\mathbf{N}=\mathbf{6 , 2 2 0}) \\
\end{array}$}} & \multicolumn{2}{|c|}{ Male } \\
\hline & $\begin{array}{r}\text { Proportion } \\
\text { of Total } \\
\text { Sample } \\
(\mathbf{N}=6,816) \\
\end{array}$ & $\begin{array}{r}\text { Mean } \\
\text { Student } \\
\text { Debt } \\
\end{array}$ & & & $\begin{array}{r}\text { Mean } \\
\text { Student } \\
\text { Debt } \\
\end{array}$ & $\begin{array}{l}\text { Standard } \\
\text { Deviation } \\
\end{array}$ \\
\hline \multicolumn{7}{|l|}{$\begin{array}{l}N \\
\text { Year }\end{array}$} \\
\hline 2002 & 0.228 & $1,713.67$ & $6,312.87$ & 0.230 & $1,653.92$ & $6,150.49$ \\
\hline 2006 & 0.228 & $2,013.07$ & $6,989.64$ & 0.225 & $2,008.35$ & $7,081.74$ \\
\hline 2010 & 0.237 & $3,150.42$ & $10,013.71$ & 0.237 & $3,071.06$ & $9,701.86$ \\
\hline 2014 & 0.307 & $5,332.48$ & $14,648.06$ & 0.308 & $5,292.49$ & $15,308.56$ \\
\hline $\begin{array}{l}\text { Gender } \\
\text { Age Category }\end{array}$ & 0.526 & $3,233.72$ & $10,586.88$ & 0.474 & $3,189.68$ & $10,800.46$ \\
\hline $16-24$ years & 0.159 & $7,356.72$ & $15,341.76$ & 0.171 & $6,709.65$ & $15,663.27$ \\
\hline $25-34$ years & 0.169 & $5,440.17$ & $13,219.40$ & 0.172 & $5,631.95$ & $13,848.34$ \\
\hline $35-44$ years & 0.182 & $1,700.90$ & $6,517.45$ & 0.178 & $1,643.92$ & $6,648.27$ \\
\hline
\end{tabular}




\begin{tabular}{|c|c|c|c|c|c|c|}
\hline $45-54$ years & 0.171 & $3,048.91$ & $11,142.00$ & 0.173 & $2,461.29$ & $10,229.24$ \\
\hline $55-64$ years & 0.133 & $1,754.63$ & $7,637.60$ & 0.133 & $2,110.82$ & $8,229.97$ \\
\hline Over 65 years & 0.169 & 239.18 & $2,526.61$ & 0.153 & 222.78 & $2,171.75$ \\
\hline Household Type & & & & & & \\
\hline Couple with children & 0.397 & $3,876.80$ & $11,436.52$ & 0.434 & $3,708.97$ & $11,650.53$ \\
\hline Couple & 0.289 & $2,705.91$ & $10,312.35$ & 0.310 & $2,616.21$ & $10,074.19$ \\
\hline Lone parent & 0.125 & $3,256.57$ & $9,832.64$ & 0.064 & $3,711.72$ & $10,868.50$ \\
\hline Lone person & 0.162 & $1,700.79$ & $6,798.95$ & 0.155 & $1,556.58$ & $6,091.57$ \\
\hline Education & & & & & & \\
\hline $\begin{array}{l}\text { Bachelor's degree } \\
\text { and above }\end{array}$ & 0.227 & $6,697.87$ & $15,510.91$ & 0.200 & $6,605.79$ & $16,878.06$ \\
\hline $\begin{array}{l}\text { Vocational } \\
\text { qualification }\end{array}$ & 0.229 & $2,248.67$ & $8,021.73$ & 0.350 & $1,905.14$ & $7,426.13$ \\
\hline $\begin{array}{c}\text { Year 11/12 } \\
\text { Socio-Economic Status }\end{array}$ & 0.544 & $2,200.15$ & $8,483.97$ & 0.449 & $2,668.23$ & $9,103.33$ \\
\hline Low SES & 0.205 & $1,814.57$ & $6,838.98$ & 0.200 & $1,744.60$ & $6,726.87$ \\
\hline Low-Mid SES & 0.199 & $2,555.75$ & $8,325.01$ & 0.199 & $2,519.67$ & $8,559.41$ \\
\hline Mid SES & 0.198 & $2,812.52$ & $10,470.54$ & 0.199 & $2,835.53$ & $11,772.44$ \\
\hline Mid-High SES & 0.199 & $4,023.11$ & $11,684.00$ & 0.196 & $4,050.57$ & $11,762.59$ \\
\hline High SES & 0.200 & $4,993.36$ & $13,909.36$ & 0.207 & $4,749.39$ & $13,410.90$ \\
\hline Wealth & & & & & & \\
\hline$<\$ 499,000$ & 0.609 & $3,242.22$ & $10,355.59$ & 0.597 & $3,305.75$ & $10,493.71$ \\
\hline$\$ 500,000-\$ 999,999$ & 0.208 & $2,942.87$ & $9,409.66$ & 0.209 & $2,686.78$ & $8,938.35$ \\
\hline
\end{tabular}




\begin{tabular}{|c|c|c|c|c|c|c|}
\hline & & & & & & \\
\hline $\begin{array}{l}\$ 1,000,000- \\
\$ 1,499,999^{\#}\end{array}$ & 0.08 & $3,266.76$ & $10,134.96$ & 0.085 & $3,138.13$ & $9,901.08$ \\
\hline$>\$ 1,500,000$ & 0.10 & $3,755.71$ & $14,045.28$ & 0.109 & $3,559.98$ & $15,405.39$ \\
\hline Personal Income & & & & & & \\
\hline Less than $\$ 19,999$ & 0.426 & $2,783.94$ & $9,725.02$ & 0.294 & $2,918.56$ & $9,672.01$ \\
\hline$\$ 20,000$ to $\$ 49,999$ & 0.355 & $3,253.39$ & $10,373.23$ & 0.303 & $3,243.22$ & $11,509.74$ \\
\hline$\$ 50,000$ to $\$ 99,999^{\#}$ & 0.180 & $4,383.82$ & $12,964.19$ & 0.278 & $3,365.32$ & $11,053.70$ \\
\hline $\begin{array}{l}\$ 100,000 \text { and over } \\
\text { Attitude to Risk-Taking }\end{array}$ & 0.038 & $2,656.18$ & $8,777.14$ & 0.125 & $3,306.46$ & $10,958.54$ \\
\hline No Risk & 0.404 & $2,945.66$ & $9,771.48$ & 0.302 & $2,638.77$ & $9,469.63$ \\
\hline Risk-Taking & 0.319 & $3,807.76$ & $11,910.35$ & 0.441 & $3,751.45$ & $12,234.34$ \\
\hline Industry & & & & & & \\
\hline $\begin{array}{l}\text { Agriculture, Forestry } \\
\text { and Fishing }\end{array}$ & 0.013 & $1,184.47$ & $5,405.14$ & 0.034 & $1,570.57$ & $6,907.44$ \\
\hline Mining & 0.003 & $2,193.33$ & $6,650.35$ & 0.018 & $2,744.48$ & $9,431.26$ \\
\hline Manufacturing & 0.029 & $3,009.83$ & $9,498.72$ & 0.091 & $2,297.24$ & $8,310.12$ \\
\hline $\begin{array}{l}\text { Electricity, Gas, } \\
\text { Water and Waste } \\
\text { Services }\end{array}$ & 0.002 & $1,891.59$ & $5,252.31$ & 0.010 & $3,434.84$ & $10,436.27$ \\
\hline Construction & 0.010 & $2,332.10$ & $7,178.67$ & 0.093 & $2,369.55$ & $8,716.59$ \\
\hline Wholesale Trade & 0.013 & $2,743.45$ & $9,048.44$ & 0.029 & $2,506.40$ & $8,194.09$ \\
\hline Retail Trade & 0.069 & $4,537.39$ & $11,828.48$ & 0.055 & $5,070.06$ & $12,355.19$ \\
\hline $\begin{array}{l}\text { Accommodation and } \\
\text { Food Services }\end{array}$ & 0.046 & $4,376.48$ & $11,576.55$ & 0.038 & $4,642.15$ & $15,937.06$ \\
\hline $\begin{array}{l}\text { Transport, Postal and } \\
\text { Warehousing }\end{array}$ & 0.120 & $1,931.24$ & $9,800.80$ & 0.045 & $2,472.19$ & $10,107.04$ \\
\hline
\end{tabular}




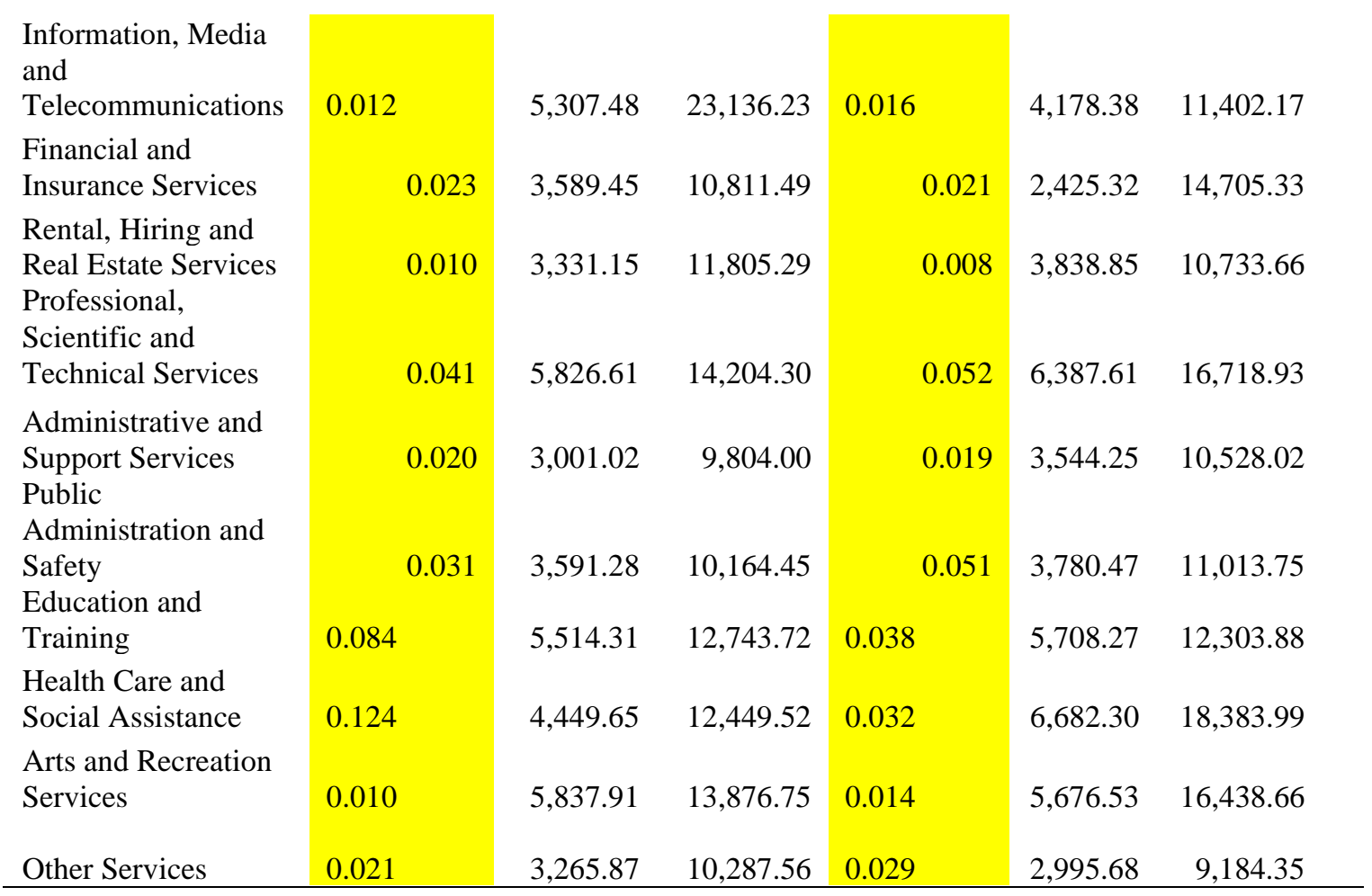


Figure 4.1. Cohort Trajectories

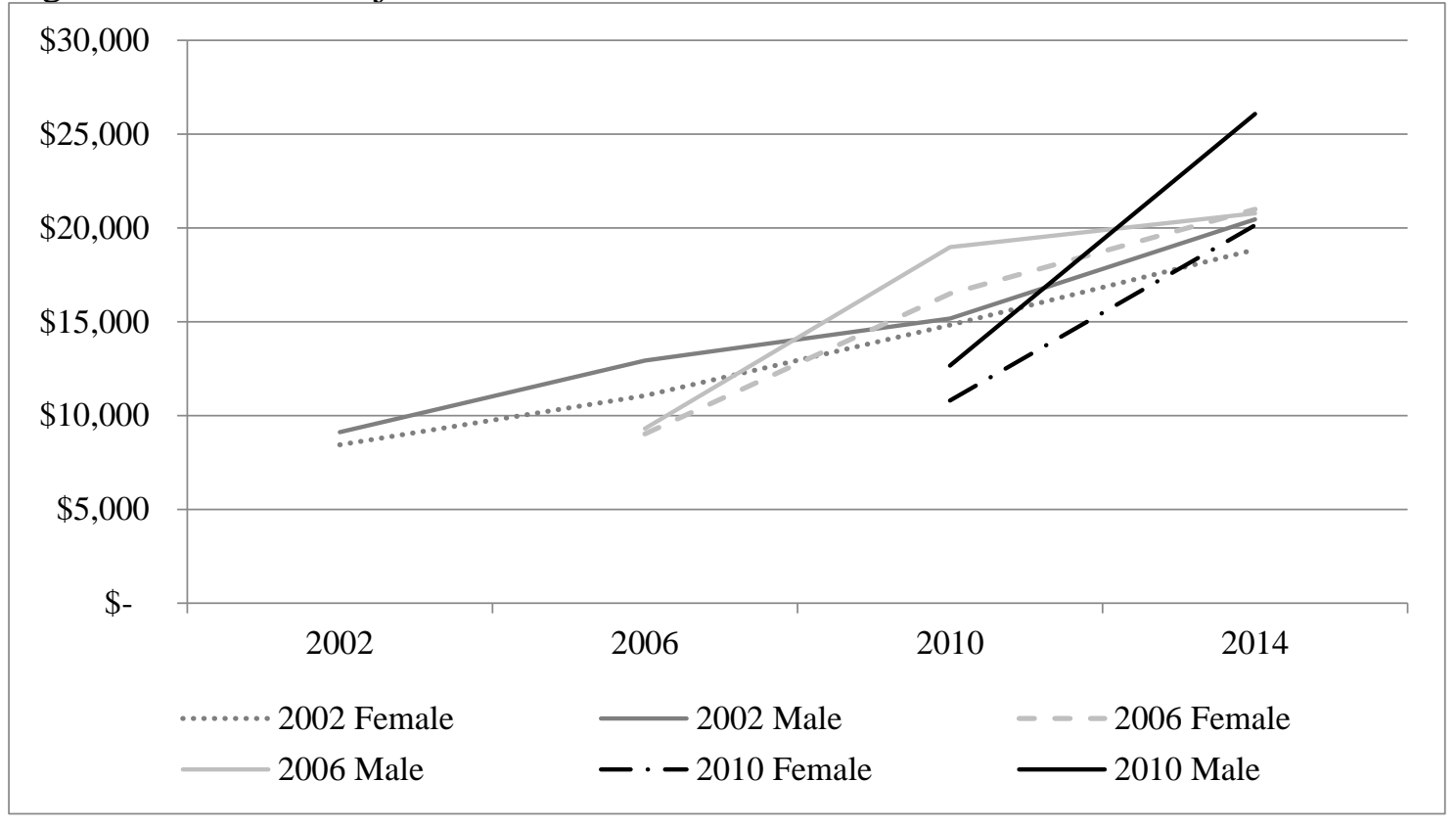


Table 4.2 Transition Tables

\begin{tabular}{|c|c|c|c|c|c|c|c|}
\hline \multicolumn{5}{|c|}{ i. $2002-2014$} & \multicolumn{3}{|c|}{ ii. $2002-2006$} \\
\hline \multirow{5}{*}{$\begin{array}{l}\text { A. } \\
\text { Female } \\
\text { HELP } \\
\text { holder }\end{array}$} & \multirow{3}{*}{\multicolumn{2}{|c|}{$\begin{array}{l}\text { Lagged Female } \\
\text { HELP holder }\end{array}$}} & A. & \multirow{5}{*}{$\begin{array}{l}\text { Lagged } \\
\text { Female } \\
\text { HELP } \\
\text { holder }\end{array}$} & \multirow[b]{5}{*}{0} & \multirow[b]{5}{*}{1} & \multirow[b]{5}{*}{ Total } \\
\hline & & & Female & & & & \\
\hline & & & HELP & & & & \\
\hline & & & & & & & \\
\hline & 0 & 1 & Total & & & & \\
\hline \multirow[t]{2}{*}{0} & 14,895 & 826 & 15,721 & 0 & 4,793 & 168 & 4,961 \\
\hline & 94.73 & 5.27 & 100.00 & & 96.61 & 3.39 & 100.00 \\
\hline \multirow[t]{2}{*}{1} & 566 & 1,088 & 1,654 & 1 & 171 & 309 & 480 \\
\hline & 34.28 & 65.72 & 100.00 & & 35.63 & 64.38 & 100.00 \\
\hline \multirow[t]{2}{*}{ Total } & 15,461 & 1914 & 17,375 & Total & 4,964 & 477 & 5,441 \\
\hline & 88.97 & 11.03 & 100.00 & & 91.23 & 8.77 & 100.00 \\
\hline \multirow{2}{*}{$\begin{array}{l}\text { B. Male } \\
\text { HELP } \\
\text { holder }\end{array}$} & \multicolumn{3}{|c|}{$\begin{array}{l}\text { Lagged Male HELP } \\
\text { holder }\end{array}$} & \multirow{2}{*}{$\begin{array}{l}\text { B. Male } \\
\text { HELP } \\
\text { holder }\end{array}$} & \multicolumn{3}{|c|}{ Lagged Male HELP holder } \\
\hline & 0 & 1 & Total & & 0 & 1 & Total \\
\hline \multirow[t]{2}{*}{0} & 13,712 & 524 & 14,326 & 0 & 4,321 & 102 & 4,423 \\
\hline & 96.32 & 3.68 & 100.00 & & 97.69 & 2.31 & 100.00 \\
\hline \multirow[t]{2}{*}{1} & 369 & 681 & 1,050 & 1 & 125 & 190 & 315 \\
\hline & 35.14 & 64.86 & 100.00 & & 39.68 & 60.32 & 100.00 \\
\hline \multirow[t]{2}{*}{ Total } & 14,081 & 1025 & 15,286 & Total & 4,446 & 292 & 4,738 \\
\hline & 92.12 & 7.88 & 100.00 & & 93.84 & 6.16 & 100.00 \\
\hline \multicolumn{4}{|c|}{ iii. 2006-2010 } & & & & $\begin{array}{l}\text { iv. } \\
2010- \\
2014\end{array}$ \\
\hline \multirow[t]{2}{*}{$\begin{array}{l}\text { A. } \\
\text { Female } \\
\text { HELP } \\
\text { holder }\end{array}$} & \multicolumn{2}{|c|}{$\begin{array}{c}\text { Lagged Female } \\
\text { holder }\end{array}$} & HELP & \multirow[t]{2}{*}{$\begin{array}{l}\text { A. } \\
\text { Female } \\
\text { HELP } \\
\text { holder }\end{array}$} & \multicolumn{2}{|c|}{$\begin{array}{l}\text { Lagged Female HELP } \\
\text { holder }\end{array}$} & \\
\hline & 0 & 1 & Total & & 0 & 1 & Total \\
\hline \multirow[t]{2}{*}{0} & 4,930 & 255 & 5,185 & 0 & 4,972 & 386 & 5,358 \\
\hline & 95.08 & 4.92 & 100.00 & & 92.8 & 7.2 & 100.00 \\
\hline \multirow[t]{2}{*}{1} & 195 & 326 & 521 & 1 & 185 & 429 & 614 \\
\hline & 37.43 & 62.57 & 100.00 & & 30.13 & 69.87 & 100.00 \\
\hline \multirow[t]{2}{*}{ Total } & 5,125 & 581 & 5,706 & Total & 5,157 & 815 & 5,972 \\
\hline & 89.82 & 10.18 & 100.00 & & 86.35 & 13.65 & 100.00 \\
\hline \multirow{2}{*}{$\begin{array}{l}\text { B. Male } \\
\text { HELP } \\
\text { holder }\end{array}$} & Lagged & $\begin{array}{l}\text { Male } \\
\text { holder }\end{array}$ & HELP & $\begin{array}{l}\text { B. Male } \\
\text { Student }\end{array}$ & Lagged Male & HELP & oolder \\
\hline & 0 & 1 & Total & $\begin{array}{l}\text { HELP } \\
\text { holder }\end{array}$ & 0 & 1 & Total \\
\hline 0 & 4,511 & 182 & 4,693 & 0 & 4,641 & 227 & 4,868 \\
\hline & 96.12 & 3.88 & 100.00 & & 95.34 & 4.66 & 100.00 \\
\hline 1 & 108 & 197 & 305 & 1 & 127 & 279 & 406 \\
\hline & 35.41 & 64.59 & 100.00 & & 31.28 & 68.72 & 100.00 \\
\hline Total & 4,619 & 379 & 4,998 & Total & 4,768 & 506 & 5,274 \\
\hline & 92.42 & 7.58 & 100.00 & & 90.41 & 9.59 & 100.00 \\
\hline
\end{tabular}




\begin{tabular}{|c|c|c|c|}
\hline \multirow[b]{2}{*}{ Variables } & \multicolumn{3}{|c|}{ Student Debt (\$) } \\
\hline & $\begin{array}{r}\text { Marginal } \\
\text { Effects }\end{array}$ & & $\begin{array}{r}\text { Jackknife } \\
\text { Standard Error }\end{array}$ \\
\hline \multicolumn{4}{|l|}{ Year } \\
\hline 2002 & $-2,255.11$ & **** & 584.31 \\
\hline \multicolumn{4}{|l|}{$2006^{\#}$} \\
\hline 2010 & $4,229.15$ & **** & 556.73 \\
\hline 2014 & $10,073.06$ & **** & 511.74 \\
\hline \multicolumn{4}{|l|}{ Gender } \\
\hline Female & $-1,127.11$ & & 762.14 \\
\hline \multicolumn{4}{|l|}{ Male $^{\#}$} \\
\hline \multicolumn{4}{|l|}{ Age Category } \\
\hline $16-24$ years & $6,466.48$ & $* * *$ & 615.94 \\
\hline 25-34 years & $3,889.79$ & $* * *$ & 593.92 \\
\hline \multicolumn{4}{|l|}{$35-44$ years $^{\#}$} \\
\hline 45-54 years & $4,235.14$ & $* * *$ & 652.42 \\
\hline 55-64 years & $4,533.33$ & $* * *$ & 817.49 \\
\hline Over 65 years & $-1,476.41$ & & $1,532.84$ \\
\hline \multicolumn{4}{|l|}{ Household Type } \\
\hline Couple with children ${ }^{\#}$ & $-5,922.36$ & $* * *$ & 807.12 \\
\hline Couple & $-3,300.50$ & $* * *$ & 825.42 \\
\hline Lone parent & $-5,417.67$ & $* * *$ & 925.08 \\
\hline Lone person & $-8,580.27$ & $* * *$ & 929.93 \\
\hline \multicolumn{4}{|l|}{ Education } \\
\hline Bachelor's degree and above & $4,827.10$ & $* * *$ & 489.88 \\
\hline Vocational qualification & $-1,474.24$ & ** & 510.42 \\
\hline \multicolumn{4}{|l|}{ Year 11/12 } \\
\hline \multicolumn{4}{|l|}{ Socio-Economic Status } \\
\hline Female $\times$ Low SES & $1,026.14$ & & $1,069.01$ \\
\hline Low SES & $-1,552.33$ & ${ }^{*}$ & 866.54 \\
\hline Low-Mid SES & -299.54 & & 601.76 \\
\hline \multicolumn{4}{|l|}{ Mid SES ${ }^{\#}$} \\
\hline Mid-High SES & $1,319.32$ & $*$ & 556.07 \\
\hline High SES & $2,714.47$ & $* * *$ & 553.57 \\
\hline \multicolumn{4}{|l|}{ Wealth } \\
\hline Female×Low Wealth & -206.84 & & 752.92 \\
\hline$<\$ 499,000$ & 300.43 & & 836.82 \\
\hline$\$ 500,000-\$ 999,999$ & -616.27 & & 752.45 \\
\hline$\$ 1,000,000-\$ 1,499,999^{\#}$ & & & 851.30 \\
\hline
\end{tabular}


$>\$ 1,500,000$

Personal Income

Female $\times$ Low Income

\begin{tabular}{|c|c|c|}
\hline $1,464.91$ & $*$ & 803.06 \\
\hline $1,118.56$ & & 755.90 \\
\hline $2,075.63$ & $* * *$ & 501.12 \\
\hline$-2,023.30$ & $* *$ & 774.99 \\
\hline-1.39 & & 787.78 \\
\hline 323.24 & & 670.21 \\
\hline 881.07 & $*$ & 464.02 \\
\hline
\end{tabular}

Less than $\$ 19,999$

$\$ 20,000$ to $\$ 49,999$

$\$ 50,000$ to $\$ 99,999^{\#}$

$\$ 100,000$ and over

Attitude to Risk-Taking

Female $\times$ No Risk

No Risk

670.21

Risk-Taking

Industry

Female $\times$ Education

246.49

$1,284.94$

Female $\times$ Health

$-5,531.60$

$1,406.99$

Agriculture, Forestry and Fishing

$-565.57$

$1,657.10$

Mining

508.91

$2,020.37$

Manufacturing

$-75.04$

927.44

Electricity, Gas, Water and Waste

Services

$-255.58$

2,306.96

Construction

$-1,298.91$

$1,021.10$

Wholesale Trade

$-997.87$

$1,416.26$

Retail Trade

$-503.47$

792.62

Accommodation and Food Services

$-1,720.60$

831.23

Transport, Postal and Warehousing

450.58

$1,332.99$

Information, Media and

Telecommunications

$-83.92$

$1,356.55$

Financial and Insurance Services

$-555.97$

$1,162.23$

Rental, Hiring and Real Estate Services

$2,423.47$

$1,926.97$

Professional, Scientific and Technical

Services

358.60

811.75

Administrative and Support Services

$-262.44$

$1,310.46$

Public Administration and Safety

$-692.32$

976.02

Education and Training

$-877.67$

$1,151.12$

Health Care and Social Assistance

$5,184.69$

$1,307.86$

Arts and Recreation Services

465.73

$1,331.36$

Other Services

$-115.09$

$1,222.08$

Number of observations

10,508

F statistic/ Wald Chi2

27.130

R-Square

0.115

Adjusted R-Square

0.111

Notes: ${ }^{*} \mathrm{p}<0.10, * * \mathrm{p}<0.05, * * * \mathrm{p}<0.01$; ${ }^{*}$ denotes the reference category. 
Marginal effects indicate the effect of each outcome on the level of Student Debt; the standard normal density function is used for the continuous variables; the marginal effects for the dummy variables are analysed by comparing the probabilities that result when the variable takes it's two different values with those that occur with the other variables held at their sample means; probabilities for all categories sum to zero. 